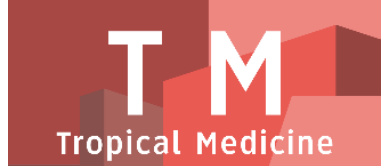

PAPER - OPEN ACCESS

\title{
Pengaruh Stimulasi Listrik Terhadap Sirkulasi Kaki Pasien Diabetes Melitus Tipe 2
}
Author
: Iskandar Iskandar
DOI
: 10.32734/tm.v1i2.216
Electronic ISSN
: 2623-0550
Print ISSN
: 2623-0542

Volume 1 Issue 2 - 2018 TALENTA Conference Series: Tropical Medicine (TM)

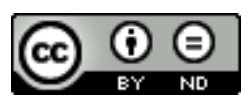

This work is licensed under a Creative Commons Attribution-NoDerivatives 4.0 International License.

Published under licence by TALENTA Publisher, Universitas Sumatera Utara
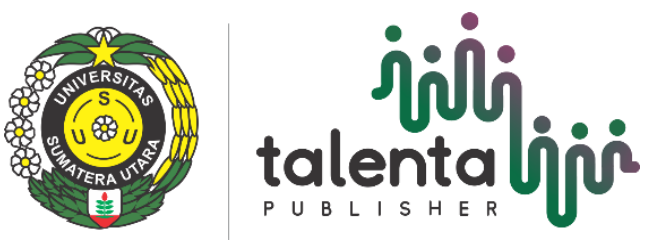


\title{
Pengaruh Stimulasi Listrik Terhadap Sirkulasi Kaki Pasien Diabetes Melitus Tipe 2
}

\author{
Iskandar $^{\mathrm{a}}$, Ridha Dhama Jaya ${ }^{\mathrm{b}}$, Yesi Ariani $^{\mathrm{a}}$ \\ ${ }^{a}$ Fakultas Keperawatan Universitas, Medan, Indonesia \\ ${ }^{b}$ Rumah Sakit Umum Pusat Haji Adam Malik Medan, Indonesia \\ isnisam@yahoo.com
}

\begin{abstract}
Abstrak
Gangguan pembuluh darah pada arteri perifer merupakan faktor yang berkontribusi dalam pengembangan luka pada kaki pasien DM sampai dengan 50\% kasus. Intervensi yang dianjurkan untuk mengurangi terganggunya aliran darah perifer dengan menggunakan stimulasi listrik yaitu untuk meningkatkan sirkulasi ke area kaki dengan menempatkan elektroda pada otot betis.Tujuan dari penelitian ini adalah untuk mengetahui perbedaan sirkulasi kaki pasien diabetes mellitus sebelum dan sesudah stimulasi listrik pada otot betis.Desain penelitian menggunakan quasi eksperimen dengan pre and post test without controldengan63 responden yang diambil secara consecutive sampling.Hasil analisa data menggunakan uji wilcoxon sebelum stimulasi listrik didapatkan nilai median ABI 0,80, sedangkan sesudah stimulasi listrik nilai median sebanyak 0,92 serta Pvalue 0,00. Artinya terdapat perbedaan sirkulasi antara sebelum dan sesudah stimulasi listrik pada pasien DM tipe 2. Disarankan kepada perawat untuk menggunakan stimulasi listrik pada pasien DM tipe 2 yang mengalami keterbatasan fisik ataupun lanjut usia
\end{abstract}

Keywords: Stimulasi Listrik; Sirkulasi; Diabetes Melitus

\section{Pendahuluan}

Diabetes melitus (DM) adalah penyakit kronis yang terjadi baik ketika pankreas tidak cukup menghasilkan insulin, atau ketika tubuh tidak dapat secara efektif menggunakan insulin yang telah dihasilkan [1]. Penyakit ini disebutkan sebagai salah satu penyebab utama penyakit kronis dan menyebabkan kehilangan anggota tubuh di seluruh dunia (Hingorani et al., 2016) [2].

International Diabetes Federation (IDF) menyebutkan bahwa prevalensi DM di dunia pada tahun 2015 mencapai 7,3 milyar orang dan diprediksi akan meningkat lagi pada tahun 2040 menjadi 9 milyar orang. IDF juga menyebutkan bahwa Indonesia saat ini berada pada posisi urutan ketujuh terbanyak penderita DM didunia dengan jumlah sebanyak 10 juta jiwa dan diprediksi akan naik pada posisi urutan ke 6 pada tahun 2040 dengan jumlah sebanyak 16,2 juta jiwa [3]. Berdasarkan hasil Riset Kesehatan Dasar terjadi peningkatan prevalensi DM di Indonesia dari 1,1\% pada tahun 2007 menjadi 2,1\% pada tahun 2013 [4].

Tingginya kadar gula dalam darah pada penderita DM dapat menyebabkan visikositas darah meningkat sehingga berpengaruh terhadap penebalan membran kapiler, dimana sel eritrosit, trombosit dan leukosit menempel pada pembuluh darah [5]. Penyempitan pembuluh darah karena penebalan menbran mengakibatkan aliran darah menjadi berkurang, sehingga menimbulkan berbagai macam komplikasi pada penderita DM [6]. 
Neuropati perifer merupakan komplikasi yang paling sering terjadi pada DM tipe 2 dan terjadi pada bagian distal ekstremitas bawah yang dapat mempengaruhi sensorik, motorik, dan sistem otonom [7]. Risiko terjadinya gangguan neuropati perifer dua sampai empat kali lebih tinggi pada penderita diabetes dibandingkan dengan penderita tanpa diabetes, meningkat seiring bertambahnya usia dan lama menderita diabetes [8]. Salah satu gejala yang muncul pada neuropati diabetes adalah luka pada kaki [9]. Gangguan pembuluh darah pada arteri perifer merupakan faktor yang berkontribusi terhadap pengembangan luka pada kaki diabetes sampai dengan 50\% kasus [10]. Intervensi yang dianjurkan untuk mengurangi efek lanjut dari terganggunya aliran darah perifer seperti latihan rutin secara teratur (jalan kaki, senam kaki, rentang pergerakan sendi) [11].

Selain dari latihan teratur dapat juga digunakan stimulasi listrik untuk meningkatkan sirkulasi ke area kaki dengan menempatkan elektroda pada otot betis. Stimulasi listrik merupakan terapi angiogenik yang dapat meningkatkan sekresi faktor pertumbuhan pada sel endotel vaskuler [12]. Adapun untuk mengetahui sirkulasi pada kaki pasien DM dapat dinilai dengan menggunakan metode ankle brachial index (ABI) yaitu membandingkan antara nilai ankle dan brakhial [13].

Tujuan dari penelitian ini adalah untuk mengetahui perbedaan sirkulasi kaki pasien diabetes mellitus sebelum dan sesudah stimulasi listrik pada otot betis.

\subsection{Lokasi dan Metode}

\section{Lokasi Penelitian}

Penelitian ini dilakukan di puskesmas rawat inap Muara Dua Kota Lhokseumawe pada pasien DM yang berobat jalan.

\section{Metode}

Desain penelitian menggunakan quasi eksperimen dengan pendekatan pre and post test without control. Pengambilan data mulai dari bulan Juli - Agustus 2017. Metode sampling yang digunakan consecutive sampling. Besar sampel ditentukan dengan power analysis dari penelitian terkait sebelumnya [14], alpha sebesar 0,05 dan power 0,80, maka jumlah sampel didpatkan sebanyak 63 responden pasien DM tipe 2.

Kriteri iklusi yang ditetapkan antara lain: umur lebih dari 45 tahun, tidak mengalami luka, tidak menderita penyakit pernapasan, penyakit cerebrovaskular, sedangkan kriteria ekslusi pasien DM dengan penyakit jantung, mengalami komplikasi pernapasan. Data dikumpulkan dengan bekerja sama pemegang program prolanis pada puskesmas untuk mengidentifikasi pasien DM sesuai dengan kriteria yang dimaksud.

Pengumpulan data dilakukan setelah mendapatkan persetuan dari responden untuk ikut serta dalam penelitian ini. Alat pengumpul data dalam penelitian ini merupakan alat yang sudah sering dipakai dalam penelitian sejenisnya, antara lain vascular dopler (Bistos Hi-dop Model BT-200), sphygmomanometer aneroid (Onemed), stimulasi listrik menggunakan Veinoplus (AD Rem Technology Paris) dengan battery type 9V, kadar gula darah diperiksa menggunakan GlucoDr tipe D-144. Sebelum pemeriksaan ABI responden terlebih dahulu dicatat usia, jenis kelamin, tinggi badan, berat badan, serta memeriksa kadar gula darah sewaktu.

Pretest dilakukan dengan mengukur sirkulasi kaki menggunakan teknik ABI pada posisi responden tidur terlentang. Selanjutnya, dilakukan intervensi yaitu pemasangan elektoda pada kedua otot betis kiri dan kanan, mesin stimulasi dinyalakan. Setelah stimulasi selama 20 menit maka mesin stimulasi akan mati secara otomatis. Setelah stimulasi selama 2 minggu dengan frekwensi 3 kali seminggu maka diukur ulang nilai ABI sebagai post test.

Analisis data dilakukan dengan menggunakan software SPSS versi 21. Distribusi kenormalan data dilakukakan uji Kolmogorov-Smirnov digunakan untuk menentukan distribusi data secara kuantitatif. Hasil uji menunjukkan bahwa data tidak berdistribusi secara normal. Selanjutnya untuk mengetahui perbedaan antara sebelum dan sesudah stimulasi listrik di gunakan uji Wilcoxon, dengan tingkat signifikan sebesar 0,05. 


\section{Hasil}

Penelitian ini mengidentifikasi beberapa karakteristik responden mayoritas berjenis kelamin wanita $(65,1 \%)$, ratarata usia responden 56,59 tahun, indeks masa tubuh 21,84, lama menderita DM 9,59 tahun (tabel 1), kadar gula darah sewaktu sebelum intervensi 304,83 g/dl dan sesudah intervensi 204,57 (tabel 2). Nilai ABI rata-rata sebelum stimulasi 0,82 mmHg (SD 0,11), ABI minimal 0,62 $\mathrm{mmHg}$ dan maksimal 1,17 mmHg. Sedangkan setelah stimulasi dikdapatkan nilai $\mathrm{ABI}$ rata-rata $0,95 \mathrm{mmHg}(\mathrm{SD} 0,08)$, $\mathrm{ABI}$ minimal $0,77 \mathrm{mmHg}$ dan maksimal $1,17 \mathrm{mmHg}$ (tabel $3)$.

Table 1. Distribusi frekuensi dan persentase karakteristik responde $(\mathrm{n}=63)$.

\begin{tabular}{llll}
\hline Karakteristik & F & $\%$ & Rata-rata \pm SD (minimal-maksimal) \\
\hline Usia Responden & 1 & 1,6 & $56,59 \pm 7,77(22-72)$ \\
- Remaja akhir $(17-25)$ & 5 & 7,9 & \\
- Dewasa akhir (36-45) & 16 & 25,4 & \\
- Lansia awal (45-55) & 39 & 61,9 & \\
- Lansia akhir $(55-65)$ & 2 & 3,2 & \\
- Manula (> 65) & & & \\
\hline Jensi Kelamin & 41 & 65,1 & \\
- Perempuan & 22 & 34,9 & \\
- Laki-laki & & & $21,84 \pm 2,93(15,11-28,65)$ \\
\hline Indeks Masa Tubuh & 4 & 6,3 & \\
- Kurus berat $\left(<17 \mathrm{~kg} / \mathrm{m}^{2}\right)$ & 3 & 4,8 & \\
- Kuru ringan $\left(17-18,5 \mathrm{~kg} / \mathrm{m}^{2}\right)$ & 48 & 76,2 & \\
- Normal $\left(18,6-25 \mathrm{~kg} / \mathrm{m}^{2}\right)$ & 6 & 9,5 & \\
- Gemuk ringan $\left(25,1-27 \mathrm{~kg} / \mathrm{m}^{2}\right)$ & 2 & 2 & \\
- Gemuk berat $\left(>27 \mathrm{~kg} / \mathrm{m}^{2}\right)$ & & & \\
\hline
\end{tabular}

Table 2. Distribusi Frekuensi dan Persentase KGDS responden ( $n=63)$

\begin{tabular}{lcccc}
\hline Kategori & \multicolumn{2}{c}{ Sebelum } & \multicolumn{2}{c}{ Sesudah } \\
& F & $\%$ & f & $\%$ \\
\hline - Normal $)<200 \mathrm{mg} / \mathrm{dl})$ & 4 & 6.3 & 37 & 58.7 \\
- Ringan $(200-300 \mathrm{mg} / \mathrm{dl})$ & 25 & 39.7 & 20 & 31.7 \\
- Sedang $(301-400 \mathrm{mg} / \mathrm{dl})$ & 24 & 38.1 & 6 & 9.5 \\
- Berat (> 400 mg/dl) & 10 & 15.9 & \multicolumn{2}{c}{$204.57 \pm 67.79$} \\
Mean \pm SD & $304.83 \pm 86.29$ & \multicolumn{2}{c}{375} \\
Min & \multicolumn{2}{c}{114} \\
Max & \multicolumn{2}{c}{570} \\
\hline
\end{tabular}

Tabel 2 menunjukkan hasil uji wilcoxon sebelum stimulasi listrik didapatkan nilai median ABI 0,80 dengan nilai minimal 0,62 dan nilai maksimal 1,17. Sedangkan sesudah stimulasi listrik nilai median sebanyak 0,92 dengan nilai minimal 0,77 dan maksimal 1,17 serta Pvalue 0,00. Artinya terdapat perbedaan sirkulasi antara sebelum dan sesudah stimulasi listrik pada pasien DM tipe 2.

Table 3. Perbedaan sirkulasi darah kaki sebelum dan sesudah intervensi $(\mathrm{n}=63)$

\begin{tabular}{cccc}
\hline & $\mathrm{n}$ & Median (minimal-maksimal) & P value \\
\hline Sebelum stimulasi listrik & 63 & $0,80(0,62-1,17)$ &
\end{tabular}




\section{Pembahasan}

Berdasarkan hasil penelitian dapat dilihat bahwa distribusi usia responden didominasi lansia akhir $(61,9 \%)$ dengan rata-rata 56,59. Salah satu faktor risiko terjadinya DM adalah usia lebih dari 45 tahun [15], karena pada usia tersebut sudah mulai terjadi penyusutan sel-sel otot rangka dan peningkatan lemak pada tubuh secara progresif yang dapat menyebabkan gangguan sistesis protein [16]. Penyusutan tersebut dapat berdampak terhadap terjadinya peningkatan kesulitan sel-sel tubuh untuk mengabsorbsi dan menggunakan insulin sehingga berisiko terjadi peningkatan kadar glukosa dalam darah [6].

Distribusi responden berdasarkan jenis kelamin pada kedua kelompok intervensi didominasi oleh perempuan $(65,1 \%)$. Hal ini dikarenakan banyak perempuan yang aktif mengikuti intervensi dari pada laki-laki, begitu juga halnya dengan kegiatan senam kebugaran jasmani yang merupakan program prolanis yang dilaksanakan puskesmas banyak diikuti oleh perempuan dibandingkan laki-laki. Menurut IDF dan WHO menyatakan bahwa tidak ada perbedaan jumlah penyandang DM antara laki-laki dan perempuan, artinya semua jenis kelamin mempunyai kesempatan yang sama untuk terjadinya penyakit ini. Perubahan kadar glukosa dalam darah lebih dipengaruhi oleh faktor lain seperti gaya hidup, faktor diet, berat badan yang berlebih serta latihan [3,1].

Distribusi responden menurut indeks masa tubuh (IMT) berdasarkan kategori Depkes RI (2014) untuk 2 kelompok intervensi berada pada kategori normal (76,2\%). IMT lebih dari $25 \mathrm{~kg} / \mathrm{m}^{2}$ merupakan faktor resiko besar terjadinya DM [6]. Pada penyandang diabetes akan mengalami penurunan berat badan yang signifikan akibat kekurangan atau resistensi insulin yang menyebabkan pemecahan protein, lipolisis yang tidak terkendali dan peningkatan kadar asam lemak bebas dalam plasma sehingga menekan metabolisme glukosa di jaringan perifer sebagai upaya memulihkan sumber energi tubuh [17].

Distribusi kadar gula darah sewaktu (KGDS) sebelum intervensi mayoritas berada pada rentang $200-300 \mathrm{mg} / \mathrm{dl}$ $(39,7 \%)$, setelah intervensi KGDS < $200 \mathrm{mg} / \mathrm{dl}(58,7 \%)$. Dari hasil tersebut terlihat adanya perubahan nilai KGDS sesudah dilakukan intervensi. Hasil ini sesuai dengan penelitian Sharma, Shenoy, dan Singh menyatakan bahwa perubahan nilai kadar glukosa darah kelompok eksperimen $(12,71 \%)$ jauh lebih tinggi dibandingkan kelompok kontrol (4,06\%) setelah satu sesi pengobatan. Setelah stimulasi listrik selama 2 minggu, kadar glukosa darah secara signifikan $(\mathrm{t}=5,026, \mathrm{P}=0,001)$ berkurang pada kelompok eksperimen, namun terjadi penurunan yang tidak signifikan pada kelompok kontrol [18]. Menurut American Diabetes Association dan Arsa et al. menjelaskan bahwa pengelolaan kadar glukosa darah penderita DM dapat diupayakan dengan cara melakukan latihan aktivitas fisik sehingga kebutuhan glukosa akan meningkat dibandingkan pada saat beristirahat. Senam kaki dan stimulasi listrik secara teratur meningkatkan absorbsi glukosa oleh jaringan selama dan sesudah dilakukan latihan, memperbaiki sensitivitas insulin dan meningkatkan translokasi transpor glukosa. Selain dari aktifitas fisik penatalaksanaan DM juga tergantung pada gaya hidup, intervensi farmakologi dengan preparat hipoglikemik oral atau insulin, monitoring glukosa darah dan edukasi atau penyuluhan kesehatan awal dan berkelanjutan [6,19].

Hasil analisis uji wilcoxon mengindentifikasikan bahwa 82,5\% responden mengalami peningkatan sirkulasi. Hasil uji statistik diperoleh nilai $\mathrm{P}$ value sebesar 0,000 artinya stimulasi listrik mempunyai pengaruh yang bermakna terhadap peningkatan sirkulasi kaki pasien DM. Hasil penelitian ini sesuai dengan temuan Asadi et al. menyatakan bahwa setelah stimulasi selama 20 menit didapatkan adanya perubahan suhu kulit perifer yang disebabkan oleh peningkatan aliran darah [20]. Penelitian Aldayel, Jubeau, Mcguigan, dan Nosaka melaporkan bahwa suhu kulit pada orang sehat meningkat secara signifikan dalam waktu 10 menit setelah induksi stimulasi listrik pada otot paha depan dibandingkan dengan kelompok kontrol [21]. Sedangkan penelitian Sandberg, Sandberg, dan Dahl induksi stimulasi listrik pada otot trapezius pada individu yang sehat selama 15 menit dapat meningkatkan sirkulasi darah di otot [22]. Sedangkan penelitian Sharma, Shenoy, dan Singh menyebutkan penurunan kadar gula darah setelah stimulasi listrik terjadi melalui kontraksi otot yang menyebabkan kebutuhan akan aliran darah menjadi lebih tinggi dan mengakibatkan penyerapan glukosa yang dibawakan oleh darah untuk metabolisme [18]. 
Ellul dan Gatt menyatakan setelah stimulasi pada otot betis dapat menyebabkan peningkatan aliran darah pada area kaki melalui penambahan faktor endogen pembuluh darah, pada gilirannya akan menurunkan nyeri yang dialami pasien diabetik [14]. Selain itu Thakral et al. peningkatan perfusi akibat stimulasi berhubungan dengan peningkatan vascular endothelial growth factor (VEGF). VEGF merupakan faktor pertumbuhan yang juga dapat menyebabkan terjadinya angiogenik [23]. Sedangkan Asadi et al., (2015) peningkatan aliran darah di area kaki dikaitkan dengan proses vasodilatasi yang disebabkan oleh stimulasi listrik pada pembuluh darah. Dengan melepaskan nitrit oxide (NO), sebagai vasodilator koroner, atau menghambat vasokonstriksi simpatis [20]. Suryadi menjelaskan peran NO berfungsi untuk melebarkan pembuluh darah, proses fagositosis dan penghambat adhesi trombosit [5].

Stimulasi listrik yang dilakukan pada otot betis dalam penelitian ini selama 20 menit dengan frekwensi 3 kali dalam seminggu selama 2 minggu, memperlihatkan adanya peningkatan sirkulasi ke area kaki. Menurut Kamali et al. bahwa penggunaan stimulasi listrik yang sering digunakan dalam praktik klinis adalah untuk menurunkan nyeri, perubahan suhu kulit dan peningkatan aliran darah [24].

\section{Kesimpulan dan Saran}

Hasil penelitian ini disimpulkan bahwa stimulasi listrik dapat digunakan sebagai terapi modalitas yang membantu untuk meningkatkan aliran darah kaki pada pasien diabetes tipe 2, terutama pada pasien lanjut usia dan mengalami keterbatasan mobilitas sensi untuk melakukan latihan pada kaki secara rutin. Hal ini dapat digunakan oleh perawat baik dirumah sakit atau puskesmas sebagi salah satu alternatif untuk meningkatkan sirkulasi kaki pada pasien DM tipe 2 yang mengalami keterbatasan fisik untuk mencegah terjadinya luka pada kaki akibat buruknya sirkulasi kaki.Hasil penelitian menunjukkan bahwa stimulasi listrik dapat digunakan untuk membantu meningkatkan sirkulasi kaki pasien diabetes tipe 2 .

\section{Referensi}

[1] WHO. (2016). Global report on diabetes, 978, 88. https://doi.org/ISBN 9789241565257

[2] Hingorani, A., Lamuraglia, G. M., Henke, P., Meissner, M. H., Loretz, L., Zinszer, K. M., ... Murad, M. H. (2016). The management of diabetic foot: A clinical practice guideline by the Society for Vascular Surgery in collaboration with the American Podiatric Medical Association and the Society for Vascular Medicine. Journal of Vascular Surgery, 63(2), 3S-21S. https://doi.org/10.1016/j.jvs.2015.10.003

[3] International Diabetes Federation. (2015). IDF diabetes atlas. International Diabetes Federation (Seventh Ed). https://doi.org/10.1289/image.ehp.v119.i03

[4] Balitbang Kemenkes RI. (2013). Riset kesehatan dasar (RISKESDAS) 2013. Laporan Nasional 2013, 1-384. https://doi.org/1 Desember 2013

[5] Suryadi. (2015). Pengkajian Luka \& Penanganannya (1st ed.). Jakarta: Sagung Seto.

[6] American Diabetes Association. (2017). Standars of medical care in diabetes - 2017. The Journal of Clinical and Applied Research and Education, 40(January).

[7] Kavak, S., Tulgar, M., \& Anlar, Ö. (2010). Effects of transcutaneous electrical nerve stimulation on motor and sensorial nerves for diabetic polyneuropathy patients by use of electromyography. Cell Membranes and Free Radical Research, 2(3), 112-116

[8] Beckman, J. A., Creager, M. A., \& Libby, P. (2002). Diabetes and atherosclerosis: epidemiology, pathophysiology, and management. Jama, 287(19). https://doi.org/10.1001/jama.287.19.2570

[9] El-Rahman, S. K. A., \& Shousha, A. A. E. F. A. (2015). Effect of an educational program on caregivers, knowledge about diabetic foot care at elderly home in Damanhur -Egypt. Journal of American Science, 11(1), 99-107.

[10] Rosales-Velderrain, A., Padilla, M., Choe, C. H., \& Hargens, A. R. (2013). Increased microvascular flow and foot sensation with mild continuous external compression. Physiological Reports, 1(7), e00157. https://doi.org/ 10.1002/phy2.157

[11] Francia, P., Anichini, R., De Bellis, A., Seghieri, G., Lazzeri, R., Paternostro, F., \& Gulisano, M. (2015). Diabetic foot prevention: The role of exercise therapy in the treatment of limited joint mobility, muscle weakness and reduced gait speed. Italian Journal of Anatomy and Embryology, 120(1), 21-32. https://doi.org/10.13128/IJAE-16470

[12] Park, R. J., Son, H., Kim, K., Kim, S., \& Oh, T. (2011). The effect of microcurrent electrical stimulation on the foot blood circulation and pain of diabetic neuropathy. Journal of Physical Therapy Science, 23(3), 515-518. https://doi.org/10.1589/jpts.23.515

[13] Maryunani, A. (2013). Perawatan luka modern (modern wound care) terkini dan terlengkap. Jakarta: In Media.

[14] Ellul, C., \& Gatt, A. (2016). Transcutaneous calf-muscle electro-stimulation: A prospective treatment for diabetic claudicants? Diabetes \& Vascular Disease Research, 13(6), 442-444. https://doi.org/10.1177/1479164116664287 
[15] Lewis, S. L., Dirksen, S. R., Heitkemper, M. M., Bucher, L., \& Camera, I. (2011). Medical-surgical nursing: Assessment and management of clinical problems. Missouri: Elsevier Mosby.

[16] Zanuso, S. (2014). Exercise: A powerful tool to manage type 2 diabetes in the ageing population. European Medical Journal, (October), 99104

[17] LeMone, P., Burke, K. M., \& Bauldoff, G. (2015). Buku ajar keperawatan medikal bedah (5th ed.). Jakarta: EGC.

[18] Sharma, D., Shenoy, S., \& Singh, J. (2010). Effect of electrical stimulation on blood glucose level and lipid profile of sedentary type 2 diabetic patients. International Journal of Diabetes in Developing Countries, 30(4), 194. https://doi.org/10.4103/0973-3930.70859

[19] Arsa, G., Lima, L. C. D. J., Motta-santos, D., Cambri, L. T., Campbell, C. S. G., Lewis, J. E., \& Simoes, H. G. (2015). Effects of prior exercise on glycemic responses following carbohydrate ingestion in individuals with type 2 diabetes. Journal of Clinical and Translational Research, 1(August), 1-9. https://doi.org/10.18053/jctres.201501.002

[20] Asadi, M. R., Torkaman, G., Mohajeri-Tehrani, M. R., \& Hedayati, M. (2015). Effects of electrical stimulation on the management of ischemic diabetic foot ulcers. Journal of Babol University of Medical Sciences, 17(7), 7-14.

[21] Aldayel, A., Jubeau, M., McGuigan, M., \& Nosaka, K. (2010). Comparison between alternating and pulsed current electrical muscle stimulation for muscle and systemic acute responses. Journal of Applied Physiology (Bethesda, Md. : 1985), 109(3), $735-744$. https://doi.org/10.1152/japplphysiol.00189.2010

[22] Sandberg, M. L., Sandberg, M. K., \& Dahl, J. (2007). Blood Flow Changes in the Trapezius Muscle and Overlying Skin Following Transcutaneous Electrical Nerve Stimulation. Physical Therapy, 87(8), 1047-1055.

[23] Thakral, G., LaFontaine, J., Najafi, B., Talal, T. K., Kim, P., \& Lavery, L. A. (2013). Electrical stimulation to accelerate wound healing. Diabetic Foot and Ankle, 4, 1-9. https://doi.org/10.3402/dfa.v4i0.22081

[24] Kamali, F., Mirkhani, H., Nematollahi, A., Heidari, S., Moosavi, E., \& Mohamadi, M. (2017). The effect of transcutaneous electrical nerve stimulation of sympathetic ganglions and acupuncture points on distal blood flow. Journal of Acupuncture and Meridian Studies. https://doi.org/10.1016/j.jams.2017.01.003 